\title{
Screening for F508del as a first step in the molecular diagnosis of cystic fibrosis ${ }^{* * * *}$
}

\author{
Pesquisa da mutação F508del como primeiro passo no \\ diagnóstico molecular de fibrose cística
}

\section{Fernando Augusto de Lima Marson, Carmen Silvia Bertuzzo, Maria Ângela Gonçalves de Oliveira Ribeiro, Antônio Fernando Ribeiro, José Dirceu Ribeiro}

\begin{abstract}
Objective: To determine the relevance of screening for the F508del mutation of the cystic fibrosis transmembrane conductance regulator gene as a first step in the genetic diagnosis of cystic fibrosis (CF) by associating the genotype with various clinical variables. Methods: We evaluated $180 \mathrm{CF}$ patients regarding the F508del mutation. The clinical data were obtained from the medical records of the patients and from interviews with their parents or legal guardians. Results: Of the 180 patients studied, 65 (36.1\%) did not carry the F508del mutation (group 0 [G0]), 67 (37.2\%) were F508del heterozygous (G1), and 48 (26.7\%) were F508del homozygous (G2). All three groups showed associations with the clinical variables. Homozygosis was associated with younger patients, younger age at CF diagnosis, and younger age at the first isolation of Pseudomonas aeruginosa (PA), as well as with higher prevalence of pancreatic insufficiency (PI) and non-mucoid PA (NMPA) colonization. In comparison with $\mathrm{G} 1+\mathrm{G} 2$ patients, G0 patients were older; first experienced clinical symptoms, digestive disease, and pulmonary disease at an older age; were older at CF diagnosis and at first PA isolation; and had a lower prevalence of $\mathrm{Pl}$ and meconium ileus, as well as of colonization by NMPA, mucoid PA, and Burkholderia cepacia. ln G1 patients, values were intermediate for age at CF diagnosis; age at first PA isolation, first pulmonary symptoms, and first clinical manifestations; MPA colonization; and OR for Pl. Conclusions: The identification of F508del in 63.9\% of the patients studied showed that this can be a useful tool as a first step in the genetic diagnosis of CF. The F508del genotype was associated with clinical severity of the disease, especially with the variables related to $\mathrm{CF}$ onset.
\end{abstract}

Keywords: Cystic Fibrosis; Cystic Fibrosis Transmembrane Conductance Regulator; Genotype; Mutation.

\section{Resumo}

Objetivo: Verificar a importância da detecção da mutação F508del no gene cystic fibrosis transmembrane conductance regulator como primeiro passo no diagnóstico genético de fibrose cística (FC), associando-se o genótipo com várias variáveis clínicas. Métodos: Foram avaliados 180 pacientes com FC quanto à mutação F508del. As variáveis clínicas foram obtidas dos prontuários médicos dos pacientes e de entrevistas com seus pais ou responsáveis. Resultados: Dos 180 pacientes estudados, 65 (36,1\%) não apresentavam a mutação F508del (grupo 0 [G0]), 67 (37,2\%) eram heterozigotos (grupo 1 [G1]), e 48 (26,7\%) eram homozigotos (grupo 2 [G2]). Todos os três grupos mostraram associações com as variáveis clínicas. A homozigose associou-se a pacientes mais jovens, menor idade ao diagnóstico e menor idade no primeiro isolamento de Pseudomonas aeruginosa (PA), bem como maior prevalência de insuficiência pancreática (IP) e colonização por PA não mucoide (PANM). $\mathrm{Na}$ comparação com os pacientes $\mathrm{G} 1+\mathrm{G} 2$, os pacientes $\mathrm{G} 0$ eram mais velhos, com início de sintomas clínicos, doença digestiva e doença pulmonar mais tardio, diagnóstico tardio, PA isolada tardiamente, e menor prevalência de IP, íleo meconial e colonização por PANM, PA mucoide e Burkholderia cepacia. Nos pacientes G1, os valores foram intermediários para idade ao diagnóstico, idade no primeiro isolamento de PA, idade no início de doença pulmonar e de manifestações clínicas, colonização por PAM e OR para IP. Conclusões: A identificação de F508del em 63,9\% dos pacientes estudados mostrou que ela pode ser uma ferramenta útil como primeiro passo no diagnóstico genético de FC. 0 genótipo F508del foi associado à gravidade clínica da doença, particularmente às variáveis relacionadas com o início da doença.

Descritores: Fibrose cística; Regulador de Condutância Transmembrana em Fibrose Cística; Genótipo; Mutação.

\footnotetext{
* Study carried out in the Department of Pediatrics, in the Molecular Genetics Laboratory, and in the Pulmonary Physiology Laboratory of the Center for Pediatric Studies, State University at Campinas School of Medical Sciences, Campinas, Brazil.

Correspondence to: Fernando Augusto de Lima Marson. Department of Pediatrics, State University at Campinas School of Medical Sciences, CEP 13081-970, P.0. Box: 6111, Campinas, SP, Brasil.

Tel. 5519 3521-8902. E-mail: fernandolimamarson@hotmail.com

Financial support: This study received financial support from the Fundação de Amparo à Pesquisa do Estado de São Paulo (FAPESP, São Paulo Research Foundation).

Submitted: 16 November 2012. Accepted, after review: 15 February 2013.

${ }^{* *}$ A versão completa em português deste artigo está disponível em www.jornaldepneumologia.com.br
} 


\section{Introduction}

Cystic fibrosis (CF) is the most common lethal genetic disease in childhood in Caucasian populations. ${ }^{(1)}$ The disease is caused by mutations in the cystic fibrosis transmembrane conductance regulator (CFTR) gene, which encodes the protein of the same name. ${ }^{(2-4)}$ Nearly 2,000 diseasecausing mutations have been observed in the CFTR gene. ${ }^{(5)}$ These mutations are classified in six classes according to the absence of changes or qualitative and quantitative changes in the CFTR protein. ${ }^{(6)}$

The most common CFTR mutation is a threenucleotide deletion that causes the absence of amino acid 508 of the normally 1,480-amino acid protein. This mutation, which lacks a single phenylalanine codon, is commonly referred to as F508del (c.1521_1523delCTT for the DNA mutation and F508del for the mutant protein). Worldwide, the main mutation of CFTR gene is F508del, with a prevalence ranging from 30-80\%. In Caucasian populations, the F508del mutation is found in approximately $70-88 \%$ of the alleles in CF patients. ${ }^{(5,7)}$ The remaining $12-30 \%$ of the alleles comprise the other 2,000 different mutations, each of which, individually, have a very low frequency (few mutations have a worldwide frequency above $0.1 \%$, but some can reach high prevalences in selected populations). ${ }^{(5,8,9)}$

The variability in CF severity is associated principally with genetic factors, such as modifier genes and CFTR mutation classes, as well as with environmental factors. ${ }^{(9-15)}$ The F508del mutation is a class 11 mutation (causing misprocessed/ misfolded CFTR proteins), and it is associated with higher clinical severity of CF. ${ }^{(9)}$

Nowadays, it is not possible to identify the full spectrum of CFTR mutations in most countries. Together with the newborn screening program that uses immunoreactive trypsinogen testing, the Brazilian public health system has currently been providing assistance for screening of CFTR gene mutations. However, because of the costs, only one mutation is screened. Therefore, studies on the screening for the F508del mutation are necessary and important because that is the only test that can be currently performed in most of the countries. In this context, the objective of the present study was to verify the importance of the screening for the F508del mutation as a first step in the genetic diagnosis of CF by associating the F508del genotype with 28 clinical variables.

\section{Methods}

This was a cross-sectional study conducted at a university center for CF between 2010 and 2011. The diagnosis of CF was confirmed by two determinations of sweat sodium and chloride (concentrations $>60 \mathrm{mEq} / \mathrm{L}$ ) in all patients. We selected 215 patients for the study. Among those, 35 patients were excluded because of the lack of clinical data or of a written informed consent.

We used the phenol/chloroform method for DNA extraction, and, in all genetic analyses, DNA concentration was $50 \mathrm{ng} / \mathrm{mL}$, determined with a spectrophotometer (NanoVue ${ }^{\mathrm{TM}}$; GE Healthcare Biosciences, Pittsburgh, PA, USA).

The determination of the F508del mutation was performed by polymerase chain reaction (PCR), using a pair of primers-sense (5'-GGC ACC ATT AAA GAA AAT ATC-3') and antisense (5'-TGG CAT GCT TTG ATG ACG (-3')-resulting in a 74-bp fragment (F508del homozygosis), a 77-bp fragment (absence of F508del), or the presence of both fragments (F508del heterozygosis). The procedure for thermal cycling consisted of initial denaturation at $94^{\circ} \mathrm{C}$ for $5 \mathrm{~min}$, subsequent denaturation at $94^{\circ} \mathrm{C}$ for $1 \mathrm{~min}$, annealing at $53.5^{\circ} \mathrm{C}$ for $1 \mathrm{~min}$, and extension at $72^{\circ} \mathrm{C}$ for $1 \mathrm{~min}$, repeated for 35 cycles, and followed by a final extension at $72^{\circ} \mathrm{C}$ for $10 \mathrm{~min}$. The PCR contained $25 \mu \mathrm{L}$ of a solution with $50 \mathrm{ng}$ of DNA, $1 \mu \mathrm{M}$ of each primer, $200 \mu \mathrm{M}$ of dNTP, $1.0 \mathrm{mM}$ of $\mathrm{MgCl}_{2}, 50 \mathrm{mM}$ of $\mathrm{KCl}, 10 \mathrm{mM}$ of Tris- $\mathrm{HCl}(\mathrm{pH}$, 8.4 at $25^{\circ} \mathrm{C}$ ), and $1.5 \mathrm{U}$ of Taq DNA polymerase. After the addition of $5 \mu \mathrm{L}$ of glycerol-based loading buffer, $10 \mu \mathrm{L}$ of the reaction product was applied on acrylamide gel..$^{(16)}$

The determination of CFTR mutations was performed in the laboratory of molecular genetics of the institution using the RFLP method (G542X, R1162X, R553X, G551D, and N1303K). Some mutations were obtained by sequencing or multiplex ligation-dependent probe amplification: S4X, 2183A>G, 1717-G>A, and 1618T. For both methods, we used the MegaBace1000 DNA sequencer (GE Healthcare Biosciences). ${ }^{(16)}$

Clinical data, anthropometric variables, pulmonary function results, and sputum or oropharyngeal swab culture results were collected.

The following clinical variables were investigated: clinical scores (ShwachmanKulczycki, Kanga, and Bhalla scores) ${ }^{(17)}$; body mass index (BMI) - for the patients older than 
19 years, we used the formula $\mathrm{BMI}=$ weight/ (height) ${ }^{2}$; for the remaining patients, we used WHO Anthro, version 3.0.1 and WHO Anthro Plus, version 1.0.2, respectively, for children under 5 years of age and for those aged 5-19 years; age (dichotomized between $\leq 154$ months and $>154$ months); age at diagnosis (dichotomized between $\leq 24$ months and $>24$ months); first digestive symptoms (dichotomized between $\leq$ 3 months and $>3$ months); first pulmonary symptoms (dichotomized between $\leq 6$ months and $>6$ months); age at the first isolation of Pseudomonas aeruginosa (dichotomized between $\leq$ 30 months and $>30$ months); airway colonization (mucoid $P$. aeruginosa [MPA], nonmucoid $P$. aeruginosa [NMPA], Achromobacter xylosoxidans, Burkholderia cepacia, and Staphylococcus aureus); transcutaneous $\mathrm{SaO}_{2}$; spirometry results; and comorbidities-nasal polyps, osteoporosis, meconium ileus (M1), diabetes mellitus, and pancreatic insufficiency (PI).

All of the scores were determined by two pediatric pulmonologists, and, in case of disagreement, a third specialist was invited to review the scores in order to determine the final results.

All of the patients aged $\geq 7$ years were submitted to spirometry with a CPFS/D spirometer (MedGraphics, Saint Paul, MN, USA). Data were recorded using Breeze PF, version 3.8B for Windows 95/98/NT (Medical Graphics Corp., Saint Paul, MN, USA), and the following variables were included: FVC, \% of predicted; FEV,$\%$ of predicted; FEV $_{1}$ I FVC ratio, \% of predicted; and $\mathrm{FEF}_{25-75 \%}$.

The present study was approved by the Research Ethics Committee of the State University at Campinas School of Medical Sciences (Protocol no. 528/2008).

For the purposes of the statistical analysis, the variables that showed non-normal distribution (age at diagnosis, age at the first pulmonary and digestive symptoms; and age at the first isolation of $P$. aeruginosa) were categorized into two groups, using as the cutoff point the median value of each variable. The data categorized by the median were divided into two cohorts with similar sample sizes.

For the clinical evaluation of the scores, $\mathrm{SaO}_{2}$, and spirometry tests, the analyses were performed without adjusting the data.

Bacteria isolated from the airways of the patients were used as markers according to the presence or absence of specific bacteria in three consecutive cultures within the last year.

Comorbidities were compared in terms of their presence or absence.

The statistical analyses were performed with the Statistical Package for the Social Sciences, version 17.0 (SPSS Inc., Chicago, IL, USA).

In order to avoid spurious data due to the problem of multiple testing, ${ }^{(18)}$ the level of significance $\alpha$ was adjusted using the Bonferroni correction for three groups: G0, without the F508del mutation (patients with no F508del on the two alleles or those whose CFTR mutation could not be determined); G1, heterozygous F508del mutation (patients with the F508del mutation on one of the alleles, with or without another CFTR mutation identified); and G2, homozygous F508del mutation (patients with F508del on both alleles).

The statistical power of the sample was calculated with the freeware $\mathrm{G}^{*}$ Power, version 3.0.5, ${ }^{(19)}$ which showed a statistical power above $80 \%$ for the analysis performed and $\alpha=0.05$, using a population of $159 \mathrm{CF}$ patients.

The data were compared with one-way ANOVA, the Kruskal-Wallis test, the Mann-Whitney U test, and Pearson's chi-square test. For the comparisons between genotypes and variables with numerical distribution, the Kruskal-Wallis test was used for F508del genotypes, and the Mann-Whitney test was used for the F508del groups. For categorical variables, we used Pearson's chi-square test and ORs.

\section{Results}

The numerical and categorical data of the clinical variables in $180 \mathrm{CF}$ patients are described in Table 1. The distribution of the patients among the groups (G0, G1, and G2) was, respectively, $65(36.1 \%), 67(37.2 \%)$, and $48(26.7 \%)$. The population was found not to be in Hardy-Weinberg equilibrium regarding the F508del mutation ( $p<$ 0.001). The distribution of the patients according to CFTR mutation genotype is shown in Table 2 .

Regarding numerical variables, $\mathrm{SaO}_{2}$ and the Shwachman-Kulczycki scores were significantly higher in $\mathrm{G} 1$ and in $\mathrm{G} 2$ than in $\mathrm{GO}(\mathrm{p}=0.034$ and $p=0.046$, respectively; Table 3).

Regarding the clinical categorical variables, G2 patients were associated with younger age in general ( $p \leq 0.001$ ), younger age at CF diagnosis $(p<0.001)$, younger age at the first isolation of 
Table 1 - Characteristics of the patients included in the study $(\mathrm{n}=180){ }^{\text {a }}$

\begin{tabular}{|c|c|}
\hline Variable & Result \\
\hline Males & 50.00 \\
\hline Age, years & $17.72 \pm 15.75(0.60-24.00)$ \\
\hline Caucasoid & 91.70 \\
\hline Underweight and extremely underweight & 22.47 \\
\hline Identification of one F508del allele & 37.20 \\
\hline Identification of two F508del alleles & 26.70 \\
\hline Age at first clinical manifestations, years & $2.90 \pm 8.88(0.00-13.00)$ \\
\hline Age at diagnosis, years & $7.62 \pm 13.63(0.00-14.23)$ \\
\hline Age at first digestive symptoms, years & $3.39 \pm 9.11(0.00-12.45)$ \\
\hline Age at pulmonary symptoms, years & $2.90 \pm 9.89(0.00-13.00)$ \\
\hline $\mathrm{SaO}_{2}, \%$ & $94.92 \pm 4.26(66.00-99.00)$ \\
\hline Bhalla score & $8.74 \pm 5.72(0.00-25.00)$ \\
\hline Kanga score & $18.85 \pm 5.84(10.00-40.00)$ \\
\hline Shwachman-Kulczycki score & $65.85 \pm 16.77(20.00-95.00)$ \\
\hline FVC, \% of predicted & $79.29 \pm 23.55(19.00-135.00)$ \\
\hline $\mathrm{FEV}_{1,} \%$ of predicted & $71.29 \pm 27.47(17.00-132.00)$ \\
\hline $\mathrm{FEV}_{1} / \mathrm{FVC}, \%$ of predicted & $83.46 \pm 15.95(37.00-137.00)$ \\
\hline $\mathrm{FEF}_{25-75 \%}$ & $59.05 \pm 35.55(7.00-150.00)$ \\
\hline Nasal polyps & 18.64 \\
\hline Diabetes mellitus & 18.64 \\
\hline Osteoporosis & 16.38 \\
\hline Pancreatic insufficiency & 79.90 \\
\hline Meconium ileus & 15.08 \\
\hline Age at first isolation of Pseudomonas aeruginosa, years & $8.55 \pm 14.45(2.00-15.00)$ \\
\hline \multicolumn{2}{|l|}{ Colonization $^{b}$} \\
\hline P. aeruginosa & 56.42 \\
\hline Mucoid $P$. aeruginosa & 42.46 \\
\hline Burkholderia cepacia & 13.97 \\
\hline Achromobacter xylosoxidans & 10.05 \\
\hline Staphylococcus aureus & 78.77 \\
\hline
\end{tabular}

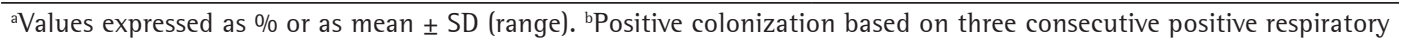
cultures in the past year.

$P$. aeruginosa $(\mathrm{p}=0.009)$, and higher prevalence of Pl ( $p=0.001)$ and NMPA ( $p=0.025$; Table 4). In comparison with $\mathrm{G} 1+\mathrm{G} 2$ patients, $\mathrm{G} 0$ patients were older ( $p<0.001)$, had first clinical symptoms at an older age $(p<0.001)$, had digestive disease at an older age $(p=0.023)$, had pulmonary disease at an older age $(p=0.006)$, were older at CF diagnosis $(p<0.001)$, had a lower prevalence of PI ( $p<0.001)$, had a lower prevalence of Ml ( $p=0.047)$, were older at the first isolation of $P$. aeruginosa $(p=0.001)$, and had a lower prevalence of colonization by NMPA $(p=0.025)$, MPA ( $p=0.068)$, and B. cepacia $(p=0.001$; Table 4). Intermediate values were found in $\mathrm{G} 1$ patients: age at CF diagnosis ( $p<0.001)$, age at the first isolation of $P$. aeruginosa $(p=0.001)$, age at first pulmonary symptoms $(p=0.006)$, age at first clinical manifestations $(p<0.001)$,
MPA colonization $(p=0.068)$, and $O R$ for PI $(p<0.001)$.

Table 5 shows the association of the major variables with the F508del genotype.

\section{Discussion}

The use of molecular genetics in the clinical practice has been improving, and it is considered important in various aspects related to patient care. The molecular technique is essential to the diagnosis of $\mathrm{CF}$, especially in cases in which there is uncertainty, i.e., when the patient presents with CF symptoms not confirmed by sweat tests, when the onset of CF symptoms occurs in adult life, in cases of atypical CF, and when CF is caused by CFTR mutations belonging to classes IV, V, or Vl. In CF patients with clinical variability, the genetic 
Table 2 - Cystic fibrosis transmembrane conductance regulator genotype according to F508del mutation group.

\begin{tabular}{|c|c|c|c|c|}
\hline & & \multicolumn{3}{|c|}{ Patient } \\
\hline F508del mutation group & CFTR mutation genotype & $\mathrm{n}$ & $\%$ & $\%$ per group \\
\hline \multirow[t]{18}{*}{$\mathrm{G} 0$} & $-1-$ & 43 & 23.9 & 36.1 \\
\hline & G542X/- & 5 & 2.8 & \\
\hline & G542X/R1162X & 1 & 0.6 & \\
\hline & G542X/1618T & 1 & 0.6 & \\
\hline & $\mathrm{G} 542 \mathrm{X} / 2183 \mathrm{~A}>\mathrm{G}$ & 1 & 0.6 & \\
\hline & $\mathrm{G} 542 X / 2183 A A \rightarrow G$ & 1 & 0.6 & \\
\hline & G542X/P205S & 1 & 0.6 & \\
\hline & G542X/R334W & 1 & 0.6 & \\
\hline & 1507V/- & 1 & 0.6 & \\
\hline & R334W/R1066C & 1 & 0.6 & \\
\hline & R334W/R334W & 1 & 0.6 & \\
\hline & $3120+1 \mathrm{G}>\mathrm{A} / 3120+1 \mathrm{G}>\mathrm{A}$ & 1 & 0.6 & \\
\hline & $3120+1 \mathrm{G}>\mathrm{A} /-$ & 1 & 0.6 & \\
\hline & TG11-5T/- & 1 & 0.6 & \\
\hline & $622-2 \mathrm{~A}>\mathrm{G} / 711+1 \mathrm{G}>\mathrm{T}$ & 1 & 0.6 & \\
\hline & R1162X/R1162X & 1 & 0.6 & \\
\hline & R1162X/- & 1 & 0.6 & \\
\hline & D110H/V232H & 1 & 0.6 & \\
\hline \multirow[t]{9}{*}{ G1 } & F508del/- & 40 & 22.2 & 37.2 \\
\hline & F508del/G542X & 13 & 7.2 & \\
\hline & F508del/R1162X & 5 & 2.8 & \\
\hline & F508del/N1303K & 4 & 2.2 & \\
\hline & F508del/R553X & 2 & 1.1 & \\
\hline & F508del/S4X & 1 & 0.6 & \\
\hline & F508del/1717-1G>A & 1 & 0.6 & \\
\hline & F508del/exon 6B-16 duplication & 1 & 0.6 & \\
\hline & F508del/2184insA & 1 & 0.6 & \\
\hline G2 & F508del/F508del & 48 & 26.7 & 26.7 \\
\hline
\end{tabular}

G0: absent F508del; G1: heterozygous F508del patients; and G2: homozygous F508del patients.

Table 3 - Significantly different numerical variables in the groups studied.*

\begin{tabular}{lccccc}
\hline \multicolumn{1}{c}{ Variable } & Genotype group & Median & Mean & SD & p \\
\hline Shwachman-Kulczycki score & $\mathrm{G} 0$ & 95 & 93.38 & 5.935 & 0.046 \\
& $\mathrm{G} 1+\mathrm{G} 2$ & 96 & 95.50 & 2.869 & \\
$\mathrm{SaO}_{2}$ & $\mathrm{G} 0$ & 60 & 61.40 & 17.844 & 0.034 \\
& $\mathrm{G} 1+\mathrm{G} 2$ & 65 & 67.91 & 15.893 & \\
\hline
\end{tabular}

G0: absent F508del; G1: heterozygous F508del patients; and G2: homozygous F508del patients. *Mann-Whitney U test.

analysis might allow a better understanding of the disease and promote targeted therapies and better outpatient care.

Molecular tests are not available in our public health care system; however, centers linked to universities screen the major CFTR mutations. Among the CFTR mutations, screening for F508del is routinely performed in our research center in all of the patients with two sodium and chloride tests in sweat with values above $60 \mathrm{mEq} / \mathrm{L}$. The screening for F508del is not expensive and allows the definitive diagnosis in $26.7 \%$ of the patients in our center, $37.2 \%$ of whom being identified as heterozygous. Our study showed that the identification of the F508del mutation is important in a country with great ethnic diversity, because $63.9 \%$ of our patients had at least one F508del allele. Therefore, the implementation of screening for F508del in the public health care system is necessary and should be implemented in all developing countries. The 


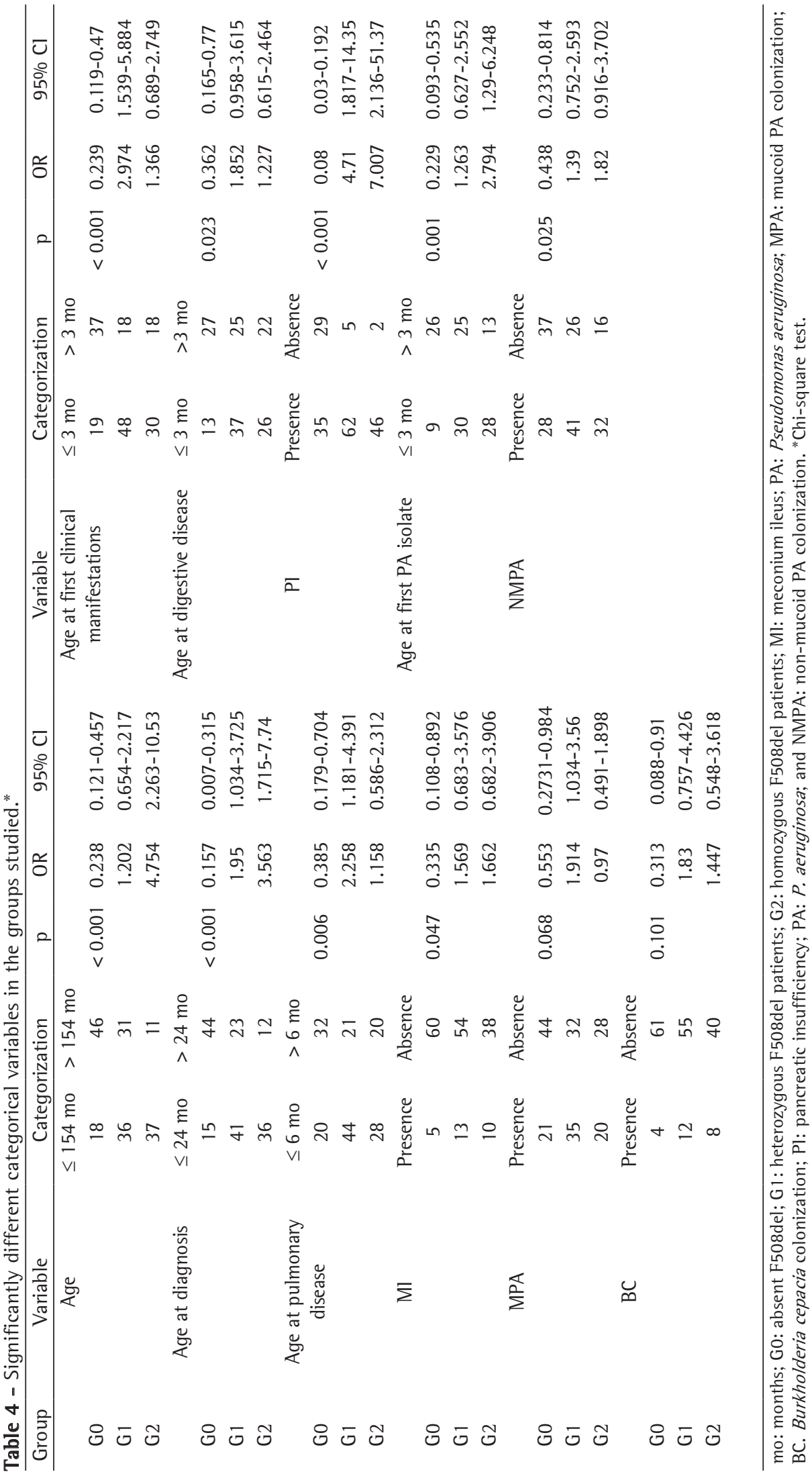


Table 5 - Variables significantly associated with the cystic fibrosis transmembrane conductance regulator genotype according to F508del mutation groups.*

\begin{tabular}{|c|c|c|c|}
\hline \multirow[t]{2}{*}{ Clinical variable } & Genotype & $\mathrm{G} 2$ vs. $\mathrm{G} 0+\mathrm{G} 1$ & G0 vs. G1+G2 \\
\hline & $\mathrm{p}$ & $\mathrm{p}$ & $\mathrm{p}$ \\
\hline Sex & 0.473 & 0.400 & 1 \\
\hline Ethnicity & 0.353 & 0.549 & 0.407 \\
\hline Age & $<0.001$ & $<0.001$ & $<0.001$ \\
\hline Age at first clinical manifestations & $<0.001$ & 0.394 & $<0.001$ \\
\hline Age at diagnosis & $<0.001$ & 0.001 & 0.01 \\
\hline Onset of digestive symptoms & 0.022 & 0.602 & $<0.001$ \\
\hline Onset of pulmonary symptoms & 0.006 & 0.731 & 0.004 \\
\hline BMl & 0.227 & 0.22 & 0.186 \\
\hline Bhalla score & 0.163 & 0.283 & 0.06 \\
\hline Kanga score & 0.509 & 0.466 & 0.264 \\
\hline Shwachman-Kulczycki score & 0.098 & 0.889 & 0.046 \\
\hline $\mathrm{SaO}_{2}$ & 0.068 & 0.076 & 0.034 \\
\hline FVC, $\%$ of predicted & 0.514 & 0.368 & 0.29 \\
\hline $\mathrm{FEV}_{1}, \%$ of predicted & 0.321 & 0.054 & 0.383 \\
\hline $\mathrm{FEV}_{1} / \mathrm{FVC}, \%$ of predicted & 0.49 & 0.232 & 0.596 \\
\hline $\mathrm{FEF}_{25-75 \%}$ & 0.29 & 0.27 & 0.132 \\
\hline Nasal polyposis & 0.521 & 0.516 & 0.842 \\
\hline Diabetes mellitus & 0.948 & 1 & 0.842 \\
\hline Osteoporosis & 0.236 & 0.255 & 0.139 \\
\hline Pancreatic insufficiency & $<0.001$ & 0.001 & $<0.001$ \\
\hline Meconium ileus & 0.047 & 0.238 & 0.016 \\
\hline First isolation of Pseudomonas aeruginosa & 0.001 & 0.009 & 0.001 \\
\hline \multicolumn{4}{|l|}{ Colonization } \\
\hline P. aeruginosa & 0.025 & 0.092 & 0.012 \\
\hline Mucoid $P$. aeruginosa & 0.068 & 1 & 0.059 \\
\hline Burkholderia cepacia & 0.332 & 0.46 & 0.04 \\
\hline Achromobacter xylosoxidans & 0.101 & 0.261 & 0.301 \\
\hline Staphylococcus aureus & 0.758 & 1 & 0.572 \\
\hline
\end{tabular}

G0: absent F508del; G1: heterozygous F508del patients; and G2: homozygous F508del patients; and BMl: body mass index. *Kruskal-Wallis one-way ANOVA (numerical data) and Pearson's chi-square test (categorical data).

identification of the F508del mutation allows improved genetic counseling.

In the state of São Paulo, newborn screening for $\mathrm{CF}$ has become possible by the determination of immunoreactive trypsinogen since 2010. Neonatal screening and sweat chloride/sodium determinations are free for all patients. Our clinic receives approximately US\$30/patient from the government for the screening for CFTR mutations. This amount allows us to perform only the screening for the F508del mutation. The identification of additional mutations is performed by funded research projects. The main objective of the present study was to assess the importance of identifying the F508del mutation in our patients, due to the current amendment for public neonatal screening in Brazil, which provides subsidies to molecular analysis in order to identify positive cases in neonatal patients, as well as studies on new drugs for CF.

In our study, we analyzed 28 clinical variables that were associated with the F508del mutation. Associations with the F508del mutation were found mainly in the variables related to the onset of the disease. No patient was diagnosed by neonatal screening in our study. Therefore, the association between the F508del genotype and the variables related to the onset of the disease, such as age at first clinical symptoms and age at diagnosis, should be related to the clinical severity and not to the diagnosis, treatment, and follow-up of the patients.

With the inclusion of a neonatal screening program for CF in the state of São Paulo in 2010, 
screening for F508del has become important as a means of predicting the clinical manifestations of $\mathrm{CF}$, enabling a better monitoring of the patients in our health care clinic.

The patients in G0 presented with a lower risk for early clinical manifestations of $\mathrm{CF}$ and a protective factor for some of the variables studied (age, age at CF diagnosis, first clinical symptoms, digestive and pulmonary diseases, Ml, and age at the first isolation of $P$. aeruginosa). In addition, there was a protective factor against MPA, NMPA, and B. cepacia colonization, which is an important risk factor for pulmonary disease. Corroborating the literature, $\mathrm{Pl}$ was less common in $\mathrm{G} 0$ than in $\mathrm{G} 1 / \mathrm{G} 2$ in our study.

The patients in $\mathrm{G} 2$ were younger, were diagnosed with $\mathrm{CF}$ at a younger age, were younger at the first isolation of $P$. aeruginosa, and were more commonly diagnosed with $\mathrm{Pl}$.

Some of the variables studied were significantly different in $\mathrm{G} 1$ than in $\mathrm{G} 0$ and $\mathrm{G} 2$ (age at first clinical manifestation, age at the onset of pulmonary disease, and MPA colonization). In addition, $\mathrm{Pl}$ and age at $\mathrm{CF}$ diagnosis showed intermediate results.

In the analysis for gene clusters regarding variables with numerical data, patients in $\mathrm{G} 1$ and G2 presented with significantly higher ShwachmanKulczycki scores and $\mathrm{SaO}_{2}$. Higher values for these variables are associated with less severe disease; however, those patients were younger, and this is associated with the variation in the Shwachman-Kulczycki score and $\mathrm{SaO}_{2}$.

When measuring the risk factors for long-term survival in a group of older CF patients ( $>40$ years of age), one group of authors reported that the residual activity of CFTR was not a factor associated with increased life expectancy but with other factors, such as BMI. ${ }^{(20)}$ The greater importance of the F508del mutation and its identification is associated with the onset of the illness. In the present study, markers of initial severity of the pathophysiology were more evidently associated with the F508del genotype than were other clinical variables. ${ }^{(20)}$ Thus, we believe that the genotype has a greater importance in the onset of disease and that the environment progressively becomes a higher risk factor with increasing age. In addition, we believe that survival selection is related to the class of mutation in the CFTR gene.
Another fact which underscores the importance of screening for F508del is that this mutation has been the most commonly studied, and the use of new drugs has been focused on patients with this mutation, which could favor their treatment. The study of correctors of F508del-CFTR depends on the use of pharmacological chaperones that stabilize the protein in its native state, of target cells using proteostasis regulators in order to enhance the folding efficiency of the protein, or of both at the same time. Although stabilizing and folding correctors of F508del-CFTR have been developed, we need to know the entire mechanism of action of these drugs before using them in our clinical practice. Current efforts to identify correctors, based largely on phenotype screens, have not been successful in identifying highly efficient molecules. ${ }^{(21,22)}$ Although there are numerous defects in the CFTR protein, some of them might be liable to correction. New treatments are aimed at correcting defective CFTR proteins. ${ }^{(22)}$

Despite the advances in the scientific knowledge on $\mathrm{CF}$, not much is known about the management of the disease, and many controversies are still present. ${ }^{(23)}$ Much remains to be learned about the mechanism that involves the expression of the CFTR protein associated with the F508del mutation, ${ }^{(24)}$ because F508del acts in multiple steps in the biogenesis of CFTR. ${ }^{25)}$

Currently, the study of the genetic variation in CF using molecular technology allows new therapeutic possibilities and provides knowledge about the unknown factors of the severity of the disease. ${ }^{(9)}$ As the prevalence of F508del is higher than that of other CFTR mutations with clinical importance described, this is the main factor to be analyzed as a first step in the molecular diagnosis of CF. Mutation analysis in a predominantly Caucasian population might provide improvements in diagnosis, genetic counseling, use of new drugs that are still under study, less expensive molecular analysis, monitoring and targeting outpatients, and promoting molecular diagnosis in individuals with a positive neonatal screening test for CF even with the low subsidy provided. There should be an understanding and an association between the outpatient clinic and the research laboratory in order to promote better patient monitoring. ${ }^{(8)}$

We currently have priority areas for the study of CF: to explore the pathogenic mechanisms of 
early pulmonary disease; to improve newborn screening; to develop a spectrum of early lung disease biomarkers that reflect the pathophysiology, the clinical course, and the response to treatment; to explore the role of genetics/genomics in the pathogenesis of the disease; to define the microbiological events in early lung disease; and to elucidate the changes in remodeling, inflammation, and repair mechanisms in the pulmonary disease. ${ }^{(26)}$ Much has yet to be done in this context, and the determination of a point mutation might bring benefits as important as those brought by the identification of other CFTR mutations.

In our study, a univariate analysis was performed. A multivariate logistic regression model could have been used; however, a larger sample of CF patients would be necessary in order to adjust for age and other factors simultaneously. For instance, a 40-year-old patient is significantly more likely to be colonized than a 5-year-old patient. In our study, we directly analyzed the influence of the F508del genotype on CF patients.

A huge ethnic diversity is present in Brazil, and, therefore, it might be disadvantageous for some subjects to be tested for F508del only. However, and not surprisingly, our findings were similar to those in the literature, and the screening for only one CF mutation was able to demonstrate the genetic diagnosis in one third of the patients. Another third of the patients presented with at least one allele with this mutation. The screening for F508del is important, particularly in developing countries and in countries with limited resources.

In conclusion, the identification of F508del and its association with the clinical severity of the disease allowed a better understanding of its influence on the clinical manifestations in CF patients. The association with variables related to the onset of the disease highlights the importance of using the screening for this mutation at the time of diagnosis and after positive neonatal screening for CF. In the future, the use of new drugs designed to one particular genotype will be associated with molecular analysis. Due to its high prevalence in the CF population, F508del should be analyzed primarily, mainly in developing countries. The genetic counseling of parents and patients is better carried out with the knowledge of the mutation associated with disease. Outpatient care can be better performed, especially considering the importance of F508del in association with CF severity variables, such as the isolation of bacteria that cause chronic pulmonary infection. In summary, the identification of F508del promotes genetic counseling, management, monitoring, diagnosis, and the use of new drugs. We believe that genetic laboratories worldwide should only initially consider the screening for F508del in patients with two altered sweat sodium/chloride tests.

\section{Acknowledgments}

We would like to thank Luciana C Bonadia, Taís DR Hortêncio, Kátia CA Aguiar, Aline Gonçalves, Simoni Avancini, Carlos E Levy, Patrícia Barbalho, and Luciana M Rezende for their assistance in data collection and organization of ideas. We would also like to thank Maria Julia Gonçalves de Oliveira Ribeiro for or her assistance in reviewing the manuscript in English.

\section{References}

1. Cystic Fibrosis Trust [homepage on the Internet]. London: Cystic Fibrosis Trust [cited 2012 May 10]. Standards for the clinical care of children and adults with cystic fibrosis in the UK. [Adobe Acrobat document, 46p.]. Available from: https://www.cysticfibrosis.org.uk/media/82070/ CD_Standards_of_Care_Dec_11.pdf

2. Kerem B, Rommens JM, Buchanan JA, Markiewicz D, Cox TK, Chakravarti A, et al. ldentification of the cystic fibrosis gene: genetic analysis. Science. 1989;245(4922):1073-80. http://dx.doi.org/10.1126/science.2570460 PMid:2570460

3. Riordan JR, Rommens JM, Kerem B, Alon N, Rozmahel R, Grzelczak Z, et al. Identification of the cystic fibrosis gene: cloning and characterization of complementary DNA. Science. 1989;245(4922):1066-73. Erratum in: Science. 1989;245(4925):1437. http://dx.doi.org/10.1126/ science. 2475911 PMid:2475911

4. Rommens JM, lannuzzi MC, Kerem B, Drumm ML, Melmer G, Dean M, et al. Identification of the cystic fibrosis gene: chromosome walking and jumping. Science. 1989;245(4922):1059-65. http://dx.doi.org/10.1126/ science.2772657 PMid:2772657

5. Cystic Fibrosis Mutation Database [homepage on the Internet]. Toronto: Cystic Fibrosis Consortium [cited 2012 Mar 06]. Available from: http://www.genet.sickkids. on.ca/cftr

6. Culling B, Ogle R. Genetic counselling issues in cystic fibrosis. Paediatr Respir Rev. 2010;11(2):75-9. http:// dx.doi.org/10.1016/j.prrv.2010.01.001 PMid:20416541

7. Cystic Fibrosis Foundation. Cystic Fibrosis Foundation Patient Registry 2011 Annual Data Report. Bethesda: Cystic Fibrosis Foundation; 2011.

8. Castellani C, Cuppens H, Macek M Jr, Cassiman JJ, Kerem E, Durie P, et al. Consensus on the use and interpretation of cystic fibrosis mutation analysis in 
clinical practice. J Cyst Fibros. 2008;7(3):179-96. http:// dx.doi.org/10.1016/j.jcf.2008.03.009 PMid:18456578 PMCid:2810954

9. Drumm ML, Ziady AG, Davis PB. Genetic variation and clinical heterogeneity in cystic fibrosis. Annu Rev Pathol. 2012;7:267-82. http://dx.doi.org/10.1146/annurevpathol-011811-120900 PMid:22017581

10. Sebro R, Levy H, Schneck K, Dimmock D, Raby BA, Cannon CL, et al. Cystic fibrosis mutations for p.F508del compound heterozygotes predict sweat chloride levels and pancreatic sufficiency. Clin Genet. 2012;82(6):54651. http://dx.doi.org/10.1111/j.1399-0004.2011.01804.x PMid:22035343

11. Collaco JM, Blackman SM, McGready J, Naughton KM, Cutting GR. Quantification of the relative contribution of environmental and genetic factors to variation in cystic fibrosis lung function. J Pediatr. 2010;157(5):802-7. http:// dx.doi.org/10.1016/j.jpeds.2010.05.018 PMid:20580019 PMCid:2948620

12. Faria EJ, Faria IC, Ribeiro JD, Ribeiro AF, Hessel G, Bertuzzo CS. Association of MBL2, TGF-beta 1 and CD14 gene polymorphisms with lung disease severity in cystic fibrosis. J Bras Pneumol. 2009;35(4):334-42. http://dx.doi.org/10.1590/S1806-37132009000400007 PMid:19466271

13. Lima CS, Ortega MM, Marson FA, Zulli R, Ribeiro AF, Bertuzzo CS. Cystic fibrosis transmembrane conductance regulator gene mutations and glutathione S-transferase null genotypes in cystic fibrosis patients in Brazil. J Bras Pneumol. 2012;38(1):50-6. http://dx.doi.org/10.1590/ S1806-37132012000100008 PMid:22407040

14. Marson FA, Bertuzzo CS, Hortencio TD, Ribeiro JD, Bonadia LC, Ribeiro AF. The ACE gene D/1 polymorphism as a modulator of severity of cystic fibrosis. BMC Pulm Med. 2012;12:41. http://dx.doi.org/10.1186/1471-246612-41 http://dx.doi.org/10.1186/1471-2466-12-50

15. Marson FA, Bertuzzo CS, Ribeiro AF, Ribeiro JD. Polymorphisms in ADRB2 gene can modulate the response to bronchodilators and the severity of cystic fibrosis. BMC Pulm Med. 2012;12:50. http://dx.doi.org/10.1186/14712466-12-41 http://dx.doi.org/10.1186/1471-2466-12-50 PMid:22950544 PMCid:3558405

16. Bonadia LC. Correlação entre aspectos clínicos, moleculares e fisiológicos de pacientes adultos com hipótese diagnóstica de fibrose cística de um centro de referência no Brasil [thesis]. Campinas: Universidade Estadual de Campinas; 2011.

17. Santos Cl, Ribeiro JD, Ribeiro AF, Hessel G. Análise crítica dos escores de avaliação de gravidade da fibrose cística:
Estado da arte. J Bras Pneumol. 2004;30(3):286-98. http://dx.doi.org/10.1590/S1806-37132004000300016

18. Drăghici S. Data analysis tools for DNA microarrays. Boca Raton: Chapman \& Hall/CRC, 2003. http://dx.doi. org/10.1201/9780203486078

19. Faul F, Erdfelder E, Lang AG, Buchner A. G*Power 3: a flexible statistical power analysis program for the social, behavioral, and biomedical sciences. Behav Res Methods. 2007;39(2):175-91. http://dx.doi.org/10.3758/ BF03193146 PMid:17695343

20. Simmonds NJ, D'Souza L, Roughton M, Alton EW, Davies JC, Hodson ME. Cystic fibrosis and survival to 40 years: a study of cystic fibrosis transmembrane conductance regulator function. Eur Respir J. 2011;37(5):107682. http://dx.doi.org/10.1183/09031936.00079010 PMid:20847077

21. Lukacs GL, Verkman AS. CFTR: folding, misfolding and correcting the $\Delta \mathrm{F} 508$ conformational defect. Trends Mol Med. 2012;18(2):81-91. http://dx.doi.org/10.1016/j. molmed.2011.10.003 PMid:22138491 PMCid:3643519

22. Thursfield RM, Davies JC. Cystic fibrosis: therapies targeting specific gene defects. Paediatr Respir Rev. 2012;13(4):215-9. http://dx.doi.org/10.1016/j. prrv.2012.04.003 PMid:23069118

23. Reddel HK, Lim TK, Mishima M, Wainwright CE, Knight DA. Year-in-review 2010: asthma, COPD, cystic fibrosis and airway biology. Respirology. 2011;16(3):540-52. http://dx.doi.org/10.1111/j.1440-1843.2011.01949.x PMid:21338438

24. Jih KY, Li M, Hwang TC, Bompadre SG. The most common cystic fibrosis-associated mutation destabilizes the dimeric state of the nucleotide-binding domains of CFTR. J Physiol. 2011;589(Pt 11):2719-31. http://dx.doi.org/10.1113/ jphysiol.2010.202861 PMid:21486785 PMCid:3112550

25. Thibodeau PH, Richardson JM 3rd, Wang W, Millen L, Watson J, Mendoza JL, et al. The cystic fibrosiscausing mutation deltaF508 affects multiple steps in cystic fibrosis transmembrane conductance regulator biogenesis. J Biol Chem. 2010;285(46):35825-35. http:// dx.doi.org/10.1074/jbc.M110.131623 PMid:20667826 PMCid:2975206

26. Ramsey BW, Banks-Schlegel S, Accurso FJ, Boucher RC, Cutting GR, Engelhardt JF, et al. Future directions in early cystic fibrosis lung disease research: an NHLBl workshop report. Am J Respir Crit Care Med. 2012;185(8):88792. http://dx.doi.org/10.1164/rccm.201111-2068WS PMid:22312017 PMCid:3360572 


\section{About the authors}

\section{Fernando Augusto de Lima Marson}

Researcher. State University at Campinas School of Medical Sciences, Campinas, Brazil.

\section{Carmen Silvia Bertuzzo}

Professor. Department of Medical Genetics, State University at Campinas School of Medical Sciences, Campinas, Brazil.

\section{Maria Ângela Gonçalves de Oliveira Ribeiro}

Professor. Department of Pediatrics, State University at Campinas School of Medical Sciences, Campinas, Brazil.

\section{Antônio Fernando Ribeiro}

Professor. Department of Pediatrics, State University at Campinas School of Medical Sciences, Campinas, Brazil.

\section{José Dirceu Ribeiro}

Professor. Department of Pediatrics, State University at Campinas School of Medical Sciences, Campinas, Brazil. 